Journal of Engineering and Applied Sciences 15 (1): 159-164, 2020

ISSN: 1816-949X

(C) Medwell Journals, 2020

\title{
A Prospect Analysis of Natural Environment for Ecotourism Development in the Archaeological Site of Bujang Valley, Kedah
}

\author{
${ }^{1}$ Adnan Jusoh, ${ }^{1}$ Yunus Sauman Sabin, ${ }^{2}$ Nasir Nayan, ${ }^{1}$ Farhana Abdullah and ${ }^{3}$ Zuliskandar Ramli \\ ${ }^{1}$ Department of History, Faculty of Human Sciences, \\ ${ }^{2}$ Department of Georgraphy and Nature Environment, Faculty of Human Sciences, \\ Universiti Pendidikan Sultan Idris, 39500 Tanjung Malim, Perak, Malaysia \\ ${ }^{3}$ Institute of the Malay World and Civilisation (ATMA), Universiti Kebangsaan Malaysia, \\ 43600 Bangi, Selangor, Malaysia
}

\begin{abstract}
This study focuses on the prospects of the natural environment for ecotourism development in Bujang valley (Kedah), a protohistoric archaeological heritage site. This is because Bujang valley has the prospects to grow as one of the potential domestic tourism destinations in this country, especially in terms of ecotourism. Blessed with the geographical endowments of hilly terrain, mountains, rivers, waterfalls, beachs, islands, bays and forest reserve, Bujang valley is a suitable destination for tourists to visit. However, with all these specialities, to what extent are the important natural prospects made use of, especially with respect to the development of ecotourism in Bujang valley? In order to answer that question, this study has applied qualitative methods by referring to books, journals and proceedings in the library. Quantitative methods were also applied in this study by conducting field research through questionnaires and interviews to identify the natural prospects for ecotourism development in Bujang valley. The findings discovered that three locations are the main choices of local tourists to visit, namely Pantai Merdeka, Tanjung Dawai and Gunung Jerai. The findings also showed that all locations with natural attractions in Bujang valley have the potential to become ecotourism areas, including Gunung Jerai, Pantai Merdeka, Pulau Sayak and Hutan Simpan Merbok. However, as a whole, in terms of popularity, Gunung Jerai is the most popular tourist destination, followed by Pantai Merdeka and Tanjung Dawai.
\end{abstract}

Key words: Bujang valley, prospect, natural environment, development, ecotourism

\section{INTRODUCTION}

Since, the 1980's, community awareness on natural sustainability has been remarkable all over the world. Among the key factors that triggered the phenomenon were the progress of the rapidly expanding education system and scientific technology. In addition, the awareness was also driven by economic benefits that urged people to think about the implications of the destruction of nature. As a result, various programmes and campaigns have emerged to bring awareness to the public on the importance of nature conservation. This development has become increasingly interesting as at the same time, awareness of the benefits of nature to the economic prospects has also expanded and resulted in the emergence of the concept of ecotourism.

In general, ecotourism is a tourism-related activity aimed at promoting small-scale tourism impacts, especially in natural areas such as national parks, state parks, expeditions, raftings and others. However, conceptually, it is an activity that brings tourists closer to nature. They may take part, be entertained and feel the pleasure of studying, visiting and discovering something new that is based on nature. It usually coincides with the programmes and activities of the lifestyle, cultural arts and heritage of the local rural community. It also provides the opportunity for tourists to experience agricultural activities directly. Tourists may take part in the locals' routine, for instance getting to navigate the oceans along with fishermen.

Meanwhile, the International Ecotourism Society (TIES) defines ecotourism as a responsible travel to natural areas that conserve the environment and sustain the well-being of local people. It carries the meaning of a travel and visit made to natural areas for the purpose of enjoying and appreciating the natural features (including present and past cultural features) which promote environmental conservation, cause low impact and enable the involvement of local communities in positive socioeconomic activities. It is therefore, very clear that ecotourism has a broad definition depending on

Corresponding Author: Adnan Jusoh, Department of History, Faculty of Human Sciences, Universiti Pendidikan Sultan Idris, 39500 Tanjung Malim, Perak, Malaysia 


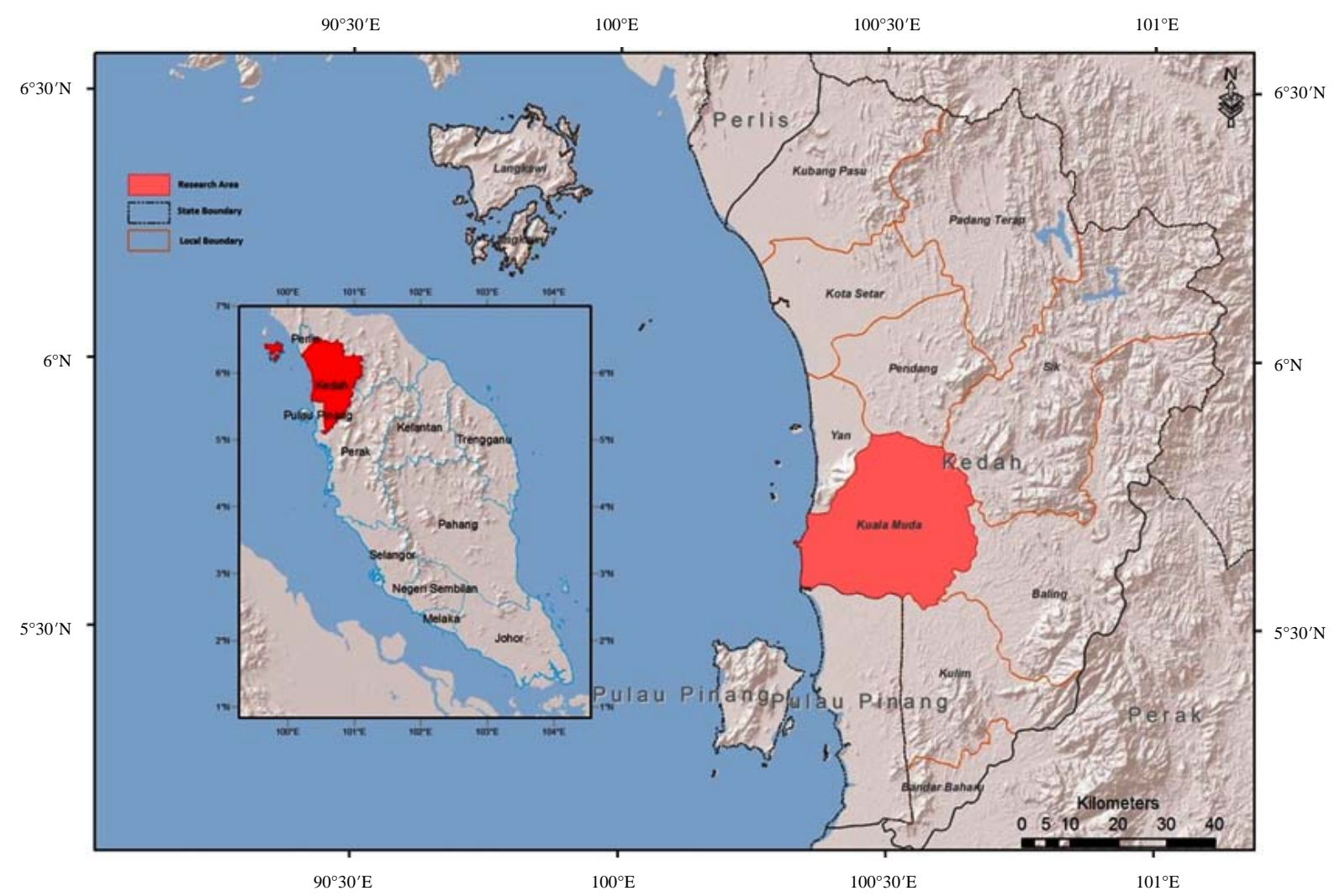

Fig. 1: Research area (Bujang valley, Kedah)

the way it is interpreted. Nevertheless, the scope of its activities is related to nature-oriented tourism while the ultimate objective is the well-being and economic benefits of the local community.

Background: Typically, there are three key goals in ecotourism, namely promoting travel or adventure to natural areas, conserving the environment and benefitting the local community. Ecotourism is not only aimed at establishing an understanding of the cultures included in the environment, conserving the ecosystem and generating economic benefits to promote environmental conservation but it also enables the involvement of local communities in positive socioeconomic activities. The main goal of ecotourism development is to provide benefits to the environment and the local community. In most travel destinations, fees charged for parking are for the conservation and preservation of the environment in the tourist area. Ecotourism also provides education, information, awareness and funding for environmental conservation efforts. Ecotourism also benefits local communities as well as visitors or tourists. Ecotourism provides economic benefits to local people whether in the form of fees, employment opportunities and sales of local crafts and products and it also gives exposure to visitors or tourists to the culture and lifestyle of the local community.

One tourist site that has long been the focus of attention and increasingly growing is Bujang valley, Kedah (Jusoh et al., 2017a, b). Bujang valley is generally known as the archaeological heritage site of the protohistoric period. However, according to historical records, Bujang valley is a site of the old Kedah kingdom which dates back to the 5-13th century AD, located on the Southern coast of Kedah between $100^{\circ} 20^{\prime}$ East and $100^{\circ} 30^{\prime}$ East longitude and $5^{\circ} 32^{\prime}$ North and $5^{\circ} 38^{\prime}$ North latitude. Originally, Bujang valley started off as a small settlement which then rapidly developed into a trading port that became the focus of traders from the east and west (Ramli and Abdul Rahman, 2013). That rapid development resulted in Bujang valley's becoming a historic site of the old Kedah kingdom from the 5-14th century $\mathrm{AD}$ and has been known, since, 150 years ago. Its importance as a centre of governance, port and intellectual centre in the Malay world has been recognised by historians. The location of the reserch area is shown in Fig. 1. 
J. Eng. Applied Sci., 15 (1): 159-164, 2020

Table 1: Location of nature-based tourism sites to be visited at Bujang valley

\begin{tabular}{ll}
\hline Category & Locations \\
\hline Mountain & Gunung Jerai \\
Waterfall & Air Terjun Seri Perigi (Seri Perigi waterfall) \\
Beach & Air Terjun Sungai Badak (Sungai Badak waterfall) \\
& Pantai Merdeka (Merdeka beach) \\
Island & Pantai Teluk Amboi (Telok Amboi beach) \\
& Pantai Teluk Nipah (Telok Nipah beach) \\
Forest/recreation park & Tanjung Dawai (fisherman village) \\
& Pulau Sayak \\
& Pulau Tiga \\
& Hutan Simpan Merbok (mangrove) \\
\hline
\end{tabular}

According to Taha (1998), the name Bujang valley had been widely used since, the 1970's, until the Department of Museums and Antiquities limited its location to an area of 144 square miles. It covers the border of Bukit Choras in the North, Sungai Muda in the south, the Straits of Malacca in the East and the North-South Expressway in the west. The Bujang valley's location is very strategic in that its geographical background is covered with three main units, namely mountains, hills and river basins. Gunung Jerai became the highest peak at about $1,300 \mathrm{~m}$ with a schist rock cover which is a rock with multiple layers of components and quartzites (Khoo, 1996). Starting from the highland, the river flows down to the valley before it reaches the Straits of Malacca. Sungai Muda and Sungai Merbok are the main rivers that irrigate Bujang valley (Rahman, 1998). The two main rivers end up in the Straits of Malacca which makes Bujang valley a very strategic position. Historical records show that the two rivers were the main trade routes between India, Arabia and China. Among the most important ports in Bujang valley which had been stopover locations for foreign traders were Kampung Sungai Mas and Pengkalan Bujang (Allen, 1988).

With such Earth surface phenomena of Bujang valley, it is indirectly a platform for potential economic activities of its population (Jusoh et al., 2017a, b). This is due to the fact that apart from the existence of archaeological remains that are already known, Bujang valley also has a beautiful coastline, hill and mountain, waterfall, bay and forest reserve. In fact, Bujang valley is also synonymous with the existence of several fishing villages that often attract the tourists who wish to experience the comfort and features of a traditional Malay community. Some of these locations are already well-known and often attract the attention of travelers, especially during public holidays. Among the locations that are suitable and can be visited by tourists in Bujang valley are those shown in Table 1.

Problem statement: While most domestic tourism destinations in Malaysia have their own specialities, the archaeological heritage site in Bujang valley has its own uniqueness. Although the name Bujang valley is established and popular as a protohistoric archaeological heritage site in Malaysia with the discovery of a number of artefacts and ruins of Buddhist or Hindu temples, there are still other elements that contribute to the arrival of tourists in the area. This is because of the interesting features of Bujang valley's topography such as mountains, lakes, islands, capes, beachs, forests and so on, contributing to the increasing number of tourist arrivals from time to time. However, it is undeniable that there is a question about the extent to which the prospects of nature can be a trigger of ecotourism activity in Bujang valley and whether the nature potentials have been amply utilised to achieve the goal of ecotourism in Bujang valley.

Objective: The main objective of this study was to analyse how far the prospects of the natural site found in the Bujang valley area go in attracting tourist arrivals to Bujang valley. This is because the name Bujang valley is already strongly characterised as a tourist location to come and see the remains of archaeological heritage and the history of the country, especially in terms of heritage tourism. However, with the potentials of some unique and interesting natural sites, it is believed that it will increase the number of tourist arrivals to Bujang valley. In other words, if the unique potential natural sites were to be developed, it would be possible to further expand the ecotourism sector in Bujang valley. In addition, the objective of this study was to search for locations or sites associated with nature around the Bujang valley area which were most popular, especially among local tourists. This is because besides the archaeological sites, there are actually some sites or natural sites with the prospect of attracting tourist arrivals in Bujang valley. In addition to that, the objective of this study is to identify the locations or sites associated with nature that have the most potential for attracting tourists to Bujang valley. This is because if the location is developed with a variety of facilities, the number of tourist arrivals to Bujang valley can be increased in the future. Indirectly, it will induce the responsible parties to make improvements in line with the feedback provided by the respondents in an effort to further develop ecotourism activities in Bujang valley (Kedah). 
Scope of study: The scope of this study was related to the prospects of the natural environment in Bujang valley (Kedah). This study was to get feedback from respondents about the prospects of nature around the Bujang valley area in attracting local tourists or foreign tourists. This is because besides the hills and mountains around Bujang valley, there are other elements of nature that also have potential to attract tourists, among which are the beauty of the beach, waterfall, rivers, mangrove forest and so on. The uniqueness of the Earth surface which comprises the elements of nature not only provides comfort for its people but is also a very important asset in terms of economic activity, particularly in terms of ecotourism development in Bujang valley.

\section{MATERIALS AND METHODS}

This study used qualitative methods by referring to sources from several libraries, among which were Tuanku Bainon Library (UPSI), Tun Sri Lanang (UKM), the National Archives of Malaysia and the Department of Museums Malaysia. In addition to interviews with several individuals involved in the research of Bujang valley, quantitative methods were also applied in this study by generating questionnaires to obtain data. The instrument used in this study was a questionnaire form, of which 150 copies were distributed to the local tourists who visited the tourist locations around Bujang valley (Kedah). Descriptive analysis (frequency and percent) through Statistical Packages for Social Sciences (SPSS) software was applied to obtain overall data distribution, while the interview data were analysed according to themes. The data analysis used basic quantitative techniques or descriptive forms such as frequency, percentage, mode and mean to examine respondents' background distribution by age, race, sex and occupation. The results of the analysis were also manifested in the form of percentages, tables, diagrams and pie charts to explain the findings more clearly.

\section{RESULTS AND DISCUSSION}

The total number of respondents involved in the questionnaire was 150 persons: 78 male respondents (52\%) and 72 female respondents (48\%). The average age of respondents was between 20 and 24 with 32 respondents (21.3\%) falling into that bracket, 28 respondents (18.7\%) were aged 30 to 34 years. There were 4 respondents aged over 50 years old. For the ethnic category, Malay was the highest with 101 respondents (67.3\%), followed by Chinese with 32 respondents (21.3\%) and Indian with 17 respondents (11.3\%). Married respondents were 76 persons (50.7\%) while single respondents were 71 persons (47.3\%), with 3 divorced respondents (2.0\%). In terms of education level, post-secondary respondents recorded a high number of either diploma holders or undergraduate degrees with 80 respondents (53.3\%), followed by secondary school with 40 respondents (26.7\%). For respondents with a Master's or Doctoral degree, there were 28 respondents (18.7\%), while only 2 respondents were without formal education.

In general, the prospect analysis of the natural environment for ecotourism of the Bujang valley's archaeological heritage site can be reviewed in many respects but this study was focused only on some of the existing locations within the Bujang valley area which were often visited by the tourists. However, the selected study locations were considered to represent the features of nature found in Bujang valley (Kedah) such as the highland category (hill or mountain), beach, forest and even the island or cape, as listed in Table 2.

Table 2 shows the location of each tourist area based on popularity among the local people. Referring to Table 5.2.7, the number of local people who visited Pantai Merdeka was 128 respondents (85.3\%), followed by Tanjung Dawai (fishing village) with 125 respondents (83.8\%). Next is Gunung Jerai with 113 respondents (75.3\%). In general, these three tourist locations are popular locations among the local people in Bujang valley. However, it was discovered that Pantai Teluk Amboi, Pulau Sayak, Pantai Teluk Nipah and Hutan Simpan Merbok (mangrove swamp) still recorded high tourist arrivals of around $49.3-64.7 \%$.

By referring to Table 3, in general, all locations that are based on natural attractions have high potential as tourist areas. According to the above data, it is clear that the highest number of respondents who visited Bujang valley chose Gunung Jerai as having potential which is $96 \%$ of the respondents. This is followed by Pantai Merdeka with $91.4 \%$ of respondents and Pulau Sayak as well as Hutan Simpan Merbok (mangrove swamp) recorded the same percentage, $80.7 \%$ of respondents.

Table 2: Popularity of the nature sites at Bujang valley

\begin{tabular}{lcc}
\hline Locations & Frequency $(\mathrm{n}=150)$ & Percentage \\
\hline Pantai Merdeka & 128 & 85.3 \\
Tanjung Dawai & 125 & 83.8 \\
Gunung Jerai & 113 & 75.3 \\
Pantai Teluk Amboi & 97 & 64.7 \\
Pulau Sayak & 95 & 63.3 \\
Pantai Teluk Nipah & 83 & 55.3 \\
Hutan Simpan Merbok & 74 & 49.3 \\
\hline
\end{tabular}

Table 3: Potential of nature-based tourism at Bujang valley

\begin{tabular}{|c|c|c|c|}
\hline \multirow[b]{2}{*}{ Locations } & \multicolumn{3}{|l|}{ Percentage } \\
\hline & Non-potential & Potential & Most potential \\
\hline Gunung Jerai & 0.0 & 4.0 & 96.0 \\
\hline Pantai Merdeka & 1.3 & 7.3 & 91.4 \\
\hline Pulau Sayak & 3.3 & 16.0 & 80.7 \\
\hline Hutan Simpan Merbok & 2.6 & 16.7 & 80.7 \\
\hline Tanjung Dawai & 3.3 & 18.0 & 78.7 \\
\hline Pantai Teluk Amboi & 4.7 & 22.6 & 72.7 \\
\hline Pantai Teluk Nipah & 2.7 & 25.3 & 72.0 \\
\hline
\end{tabular}




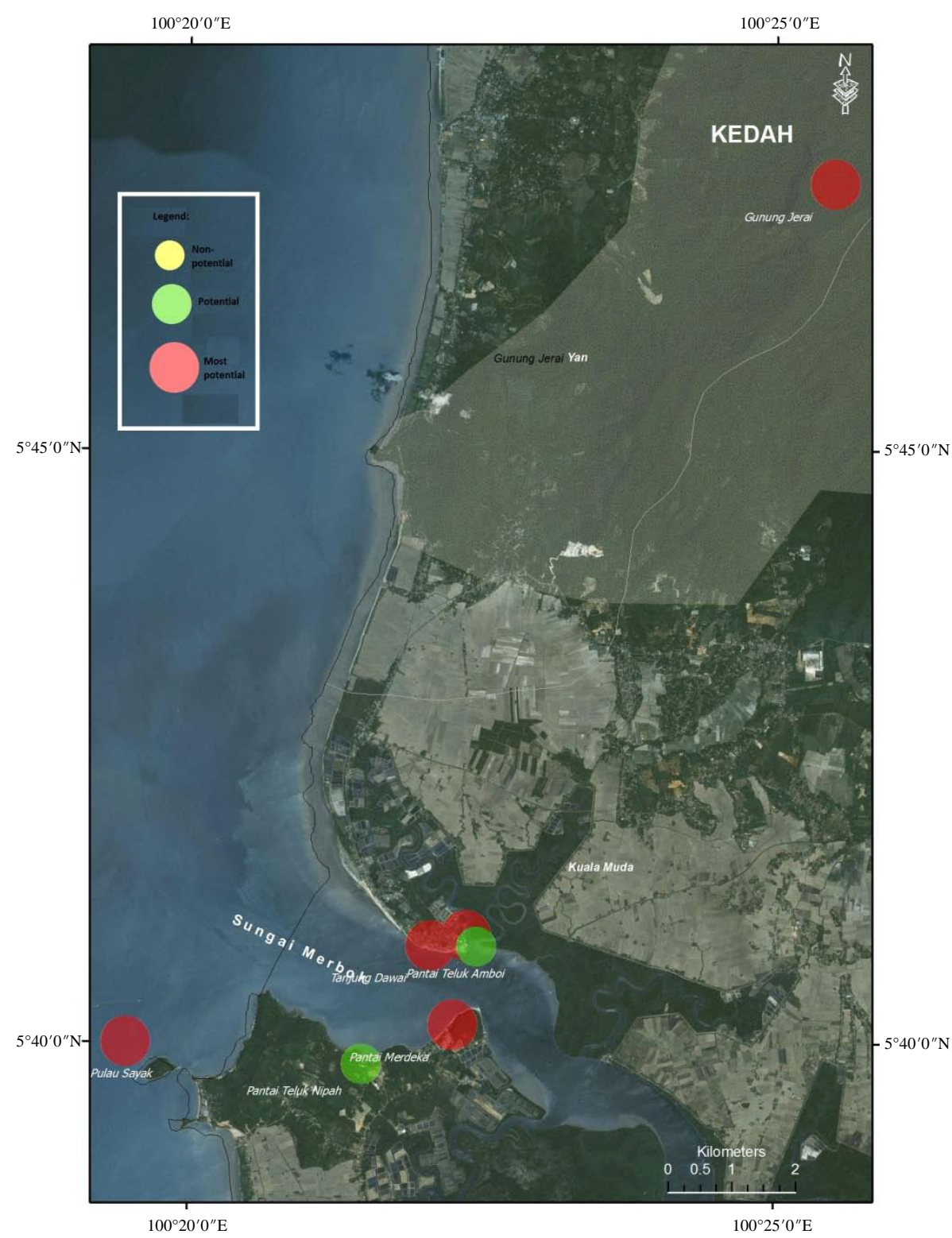

Fig. 2: Potential location for nature-based tourism at Bujang valley

Table 4 shows the position of each tourist area based on popularity among tourists. By referring to Table 4, the number of tourists who visited Gunung Jerai was $98.7 \%$ (148 respondents) of the total respondents. This shows that almost all respondents visited Gunung Jerai and clearly proved that Gunung Jerai is one of the most popular ecotourism destinations in Bujang valley. Next, the second most popular location in Bujang valley is Pantai Merdeka with $87.3 \%$ (131 respondents), followed by Tanjung Dawai (fishing village) with $85.3 \%$ (128 respondents). The two tourist destinations listed at the bottom are Pantai Teluk Nipah and Pantai Teluk Amboi. Despite being at the bottom of the list, it is still gaining attention as the percentage of visitors who have visited these sites are $73 \%$ of all respondents.

Table 5 shows the potential for nature-based tourism areas at Bujang valley archaeological heritage site. The final results of the analysis revealed that for a nature-based tourism site, the respondents had generally chosen all the listed locations as having the potential as ecotourism centres. Gunung Jerai recorded the highest number with $93.2 \%$ of respondents, followed by Pantai Merdeka (85.6\%) and Tanjung Dawai (fishing village) (80.9\%). The percentage of respondents who stated the locations listed as not having potential is low, with all locations having a minimum percentage of $68.7 \%$ (potential) (Fig. 2). 
Table 4: Popularity position of nature-based tourism area at Bujang

\begin{tabular}{lcc}
\multicolumn{1}{c}{ valley } & Frequency $(\mathrm{n}=150)$ & Percentage \\
\hline Locations & 148 & 98.7 \\
Gunung Jerai & 131 & 87.3 \\
Pantai Merdeka & 128 & 85.3 \\
Tanjung Dawai & 118 & 78.7 \\
Hutan Simpan Merbok & 113 & 75.3 \\
Pulau Sayak & 110 & 73.3 \\
Pantai Teluk Nipah & 110 & 73.3 \\
Pantai Teluk Amboi & &
\end{tabular}

$\underline{\text { Table 5: Potential of nature-based tourism at Bujang valley }}$

\begin{tabular}{lccc}
\hline & Percentage (\%) & & \\
\cline { 2 - 4 } Locations & Non-potential & Potential & Most potential \\
\hline Gunung Jerai & 0.0 & 6.8 & 93.2 \\
Pantai Merdeka & 0.8 & 13.6 & 85.6 \\
Tanjung Dawai & 3.1 & 16.0 & 80.9 \\
Hutan Simpan Merbok & 0.8 & 20.5 & 78.7 \\
Pulau Sayak & 0.9 & 21.4 & 77.8 \\
Pantai Teluk Nipah & 2.6 & 26.3 & 71.1 \\
Pantai Teluk Amboi & 2.6 & 28.7 & 68.7 \\
\hline
\end{tabular}

\section{CONCLUSION}

Bujang valley archaeological site is a site of the Old Kedah (Kedah Tua) kingdom that existed around the 5-13th century AD. The site is also synonymous with the remains of protohistoric archaeological heritage due to the discovery of a number of artefacts and Buddhist or Hindu temples. Other than that, Bujang valley is also blessed with unique forms of Earth surface such as mountain, hill, island, beach, waterfall, reserve forest and so on which are potential assets in the tourism industry. Bujang valley's special features indirectly attract visitors who seek peace and quiet while enjoying the unique beauty of nature.

Based on the results of the study, it is found that the extremely popular tourist destinations are Gunung Jerai and Pantai Merdeka. Nonetheless, Tanjung Dawai and Hutan Simpan Merbok are also the focus of local tourists due to their own attractions. However, it is undeniable that there are other potential sites that can be developed if they are built up in a well-planned and comprehensive manner. The never-ending visits of tourists are a sign that Lembah Bujang has a bright future in the ecotourism sector. However, this prospect requires various stakeholders to work integrally which include the federal government, the state government, private sector, NGOs, individuals and so on.

\section{ACKNOWLEDGEMENT}

This study was carried out with the assistance of the Fundamental Research Grant Scheme (FRGS) (2017-0080-108-02). The authors wish to express their gratitude to Minister of Higher Education (MOHE) and UPSI who provided the research fund and the parties involved in this research.

\section{REFERENCES}

Allen, J., 1988. Trade, transportation and tributaries: Exchange, agriculture and settlement distribution in early historic-period Kedah, Malaysia. Ph.D Thesis, University of Hawaii at Manoa, Honolulu, Hawaii.

Jusoh, A., K. Ariffin, N. Nayan, Y. S. Sabin, F. Abdullah, Z. Ramli and R.M.A. Zakaria, 2017b. Analysis of local community's involvement in the archaeotourism sector in Lembah Bujang, Kedah. Soc. Sci., 2: 1377-1383.

Jusoh, A., Y.S. Sabin, N. Nayan and Z. Ramli, 2017a. Archaeotourism and its attractiveness in the context of heritage tourism in Malaysia. Int. J. Acad. Res. Bus. Social Sci., 7: 1162-1174.

Khoo, T.T., 1996. Geomorphological evolution of the Merbok estuary area and its impact on the early state of Kedah, Northwest Peninsular Malaysia. J. Southeast Asian Earth Sci., 13: 347-371.

Rahman, N.H.S.N.A., 1998. Early History. Archipelago Press, Singapore.

Ramli, Z. and N.H.S.N. Abdul Rahman, 2013. Composition analysis of ancient bricks, Candi bukit Kechil, BUjang valley, Kedah. Res. J. Applied Sci. Eng. Technol., 6: 924-930.

Taha, A.H., 1998. Bujang valley historical park, Kedah. Malaysian Mus. J., 34: 1-16. 